S. Afr. J. Agric. Ext.

Vol. 44, No. 2, 2016: $195-215$

Ekepu \&

Tirivanhu.

DOI: http://dx.doi.org/10.17159/2413-3221/2016/v44n2a421

(Copyright)

\title{
ASSESSING SOCIO-ECONOMIC FACTORS INFLUENCING ADOPTION OF LEGUME-BASED MULTIPLE CROPPING SYSTEMS AMONG SMALLHOLDER SORGHUM FARMERS IN SOROTI, UGANDA
}

\author{
Ekepu, D. ${ }^{43} \&$ Tirivanhu, P. ${ }^{44}$
}

Correspondence Author: D. Ekepu. Email: dekepu@gmail.com

\begin{abstract}
Despite the numerous benefits of legume-based multiple cropping systems in soil fertility management, most smallholder sorghum farmers have not adopted them. The aim of this study was to examine socio-economic factors influencing adoption of legume-based multiple cropping systems among smallholder sorghum farmers in Soroti, Uganda. A survey questionnaire was administered to a randomly selected sample of 120 respondents. Logistic regression analysis was performed to ascertain socio-economic factors influencing adoption of legume-based multiple cropping systems. Focus group discussions were also conducted to triangulate the findings. Results showed that $51.7 \%$ of the respondents had adopted sorghumlegume rotations compared to only $8.3 \%$ who adopted sorghum-legume intercropping. Number of extension contacts had a positively significant $(p<0.05)$ effect on adoption of sorghum-legume rotations whereas family size had a negatively significant $(p<0.05)$ effect on adoption of sorghum-legume intercropping. From focus group discussions, market access to legume crops also emerged as a barrier to adoption of legume-based multiple cropping systems. The study recommends strengthening legume value chains; improving extension service delivery and conducting a cost-benefit analysis of adopting legume-based multiple cropping systems. The implication to extension service delivery is that extension agents should focus their technology dissemination messages on technologies that are accepted and feasible in their farming communities.
\end{abstract}

Keywords: Adoption; legumes; multiple cropping; socio-economic factors; extension service

\section{INTRODUCTION}

There is growing demand for food in the world to meet the needs of the increasing human population that is expected to reach 9 billion by 2050 (Alexandratos \& Bruinsma, 2012:1; Escobar et al., 2009:1286). In addition demand for agricultural raw materials has increased for industries such as beer brewing and fuel (United Nations Global Compact, 2012: 13-14; Escobar et al., 2009:1275; Martin, 2008:1). Although increasing crop production in subSaharan Africa is a target for most countries, continuous decline in the quality of production factors especially soil fertility remains a challenge for most smallholder farmers.

Traditional systems of soil fertility management such as fallowing were prevalent in most sub-Saharan African countries between 1950s-1960s (Parsons as cited in Ebanyat et al., 2010:498). However, these extensive soil fertility management practices have almost disappeared due to high population pressure on arable land (Ojiem et al., 2014:175). In most

\footnotetext{
${ }^{43}$ Masters Candidate, Centre for Sustainable Agriculture, Rural Development and Extension, University of the Free State, Bloemfontein 9300, South Africa. Email: dekepu@ gmail.com

${ }^{44}$ Post Doctoral Fellow, Centre for Sustainable Agriculture, Rural Development and Extension, University of Free State, Bloemfontein, 9300, South Africa. Email: ptirivanhu@ gmail.com
} 
S. Afr. J. Agric. Ext.

Vol. 44, No. 2, 2016: $195-215$

Ekepu \&

Tirivanhu.

DOI: http://dx.doi.org/10.17159/2413-3221/2016/v44n2a421

(Copyright)

Asian countries, intensification has resulted in improved productivity, while most parts of sub-Saharan Africa (SSA) are experiencing low crop yields and productivity. Fuglie \& Rada (2013:12) reported that increase in agricultural productivity in SSA from the early 1980s to 2008 was due to expansion in arable land, but growth in cropping intensity stayed below $1.0 \%$ throughout this period. The lack of incentives for small holder farmers to intensify crop production through fertilizer use mainly due to high cost and limited access to credit (Woniala \& Nyombi, 2014:5; Kaizzi et al., 2012:109). The systems of intensification of production should be sustainable to meet current needs without negatively impacting on the ability of future generations to meet their own needs (World Bank, 2006: 2).

In Uganda, the growth of market-oriented agriculture has raised optimism for agricultural development. For instance, contract production of sorghum variety, Epuripur under the eagle lager initiative brought socio-economic benefits to the smallholder farming communities in the form of increased food security and incomes (USAID, 2010: 55; Ebiyau, Arach \& Serunjogi, 2005:695). Sorghum in Uganda has become a major cash crop for smallholder farmers, and by 2009 farmers earned 70\% of their household income from direct sorghum sales (Geary, 2009: 33). Figures from 2014 show that 20000 farmers were producing sorghum on a contract basis (SABMiller, 2014:27). However, there is a challenge of low external input use in sorghum production to replenish soil fertility.

Recent literature on soil fertility in Uganda indicates that soils within the smallholder farms are experiencing negative nutrient balances (Turinawe, Mugisha and Drake, 2015:712; Woniala \& Nyombi, 2014:5) which show a deterioration from a report published by USAID (2010:55) indicating Ugandan soils as extremely fertile. During the periods 1961-2007 yield increases ${ }^{45}$ for sorghum were through expansion of acreage under cultivation, but due to increasing population, opening up new areas is no longer possible ${ }^{46}$. A large proportion of sorghum producers in Uganda $(95 \%)$ are smallholder farmers who do not apply optimal quantities of fertilizer in sorghum production (Mbogo, 2013:10; AATF, 2011:6). The low adoption of fertilizer calls for other innovative approaches for maintaining soil fertility by smallholder sorghum producers in Uganda.

Low technology adoption ${ }^{47}$ in Uganda has been reported to be responsible for low productivity and commercialization of the agricultural sector (Semana as cited in Ali et al, 2007). Like many sub-Saharan African countries, adoption of soil fertility management technologies has remained modest. Several factors influence the adoption of agricultural technologies and these are categorized into institutional, biophysical, technology and socioeconomic factors. Studies on adoption can either be centred on a single agricultural technology or composite technology constituents (Lambrecht, Vanlauwe \& Maertens, 2016:102). Therefore to drive adoption of agricultural technologies, there is need to answer questions such as; what categories of farmers are adopters and/or non-adopters? And what factors influence farmer decision to adopt technologies? (Mugwe et al., 2009:63). The factors that influence the adoption of technologies vary from region to region but recent findings have suggested that socio-economic factors are the most crucial factors influencing adoption of soil fertility management technologies (Lambrecht et al., 2016:115; Chiputwa et al., 2011:1). For example studies on adoption of integrated soil fertility management in Eastern

\footnotetext{
${ }^{45} 54 \%$ of sorghum yield increases in Uganda from 1961-2007 can largely be attributed expansion of the area under cultivation (Factfish, 2015)

${ }^{46}$ Between 2002 and 2014, Uganda average annual population growth rate was 3.0\% (UBOS, 2015: 13)

${ }^{47}$ Adoption here refers to the process by which a technology spreads through the farming community
} 
S. Afr. J. Agric. Ext.

Vol. 44, No. 2, 2016: $195-215$

Ekepu \&

DOI: http://dx.doi.org/10.17159/2413-3221/2016/v44n2a421

Tirivanhu.

(Copyright)

Democratic Republic of Congo found that socio-economic factors generally influenced technology adoption. They recommended more socio-economic research in order to design and implement sustainable soil fertility enhancing technologies that are applicable in the different farming contexts (Lambrecht et al., 2016:102). Studies by Mugwe et al. (2009:73) also assert that socio-economic factors play a crucial role in soil fertility technology adoption in Kenya. It is against this background that this research intends to explore the influence of socio-economic factors on the adoption of legume based multiple cropping in Uganda and add knowledge to this growing discourse.

Legume-based multiple cropping of cereals has long been reported to enhance yield of both components (Rao, Rego \& Willey, 1987:167) as well as improve soil fertility through nitrogen fixation (Lithourgidis et al., 2011:396). Legume-based multiple cropping of cereals refers to the rotation and /or intercropping of legumes with cereals. The nature of a cropping system has also been reported to have an influence on the rate of soil degradation particularly soil fertility (Oriola \& Bamidele, 2012:34). Since the use of fertilizer in sorghum production among small scale farmers in Uganda is capital intensive (Mitaru et al., 2012:12), sorghumlegume rotations and/or intercrops offer a cheaper and sustainable pathway to soil fertility management. Although multiple cropping is common in other countries such as rift valley provinces of Kenya, Rwanda, Malawi and the southern highlands of Tanzania, in Uganda sorghum is grown as a sole crop (USAID, 2010: 50) and adoption of multiple cropping has remained low among smallholder sorghum farmers.

In Uganda, several research institutions, government departments and NGOs including; International Institute of Tropical Agriculture (IITA), International Centre for Tropical Agriculture (CIAT), World Vision, Africa 2000 Network, and Ministry of Agriculture Animal Industry and Fisheries (MAAIF) have promoted the use of improved legume intercropping and rotations among smallholder cereal cropping systems. However, uptake of these technologies still lags behind on- station scientific research findings and yet the causes of limited adoption of these technologies have not been fully explored. Since socio-economic factors have been found to play a big role in soil fertility technology adoption, increasing our understanding of the impacts of such factors is critical. This will improve knowledge on technology adoption and design appropriate soil fertility management practices. Recommendations on the crucial socio-economic factors that affect adoption in the different farming contexts can also be drawn. Currently socio-economic research has focused more on composite soil fertility technologies that are adopted in packages such as conservation agriculture (CA), integrated soil fertility management, integrated nutrient management and others, yet farmer adoption of these technologies in each of these packages occurs in 'piece meal'. Therefore, it is necessary to concentrate on soil fertility management technologies that are currently feasible in the Ugandan farming context. It is also well documented that farmers always adopt cheaper technologies first, and then progress to capital intensive ones. Since multiple cropping systems such as crop rotation and intercropping are among the cheapest technologies on the soil fertility technology continuum, emphasis on studying the adoption of these technologies is important. Some studies conducted in Zimbabwe highlighted the significance of socio-economic factors on adoption of crop rotations (Chiputwa et al., 2011:1) and intercropping in Zambia (Mutibo, 2012:1), but in Uganda, there are still very few empirical studies on effects of socio-economic factors on the adoption of legume-based multiple cropping systems among smallholder sorghum farmers. This study aims at filling this research gap. 
S. Afr. J. Agric. Ext.

Vol. 44, No. 2, 2016: $195-215$

Ekepu \&

DOI: http://dx.doi.org/10.17159/2413-3221/2016/v44n2a421

Tirivanhu.

(Copyright)

The main objectives of this study are; establishing whether socio-economic factors influence the adoption of legume-based multiple cropping systems among smallholder sorghum farmers in Soroti, Uganda; determining the extent of adoption of legume-based multiple cropping among smallholder sorghum farmers; and provide recommendations for promoting the adoption of legume-based multiple cropping systems. The findings generated from this study will be relevant to researchers involved in agricultural development and extension workers engaged in the dissemination of these legume-based multiple cropping technologies. Policy makers will also benefit with regards to formulation of evidence-based strategies for sustainable soil fertility management.

\section{CONCEPTUAL ISSUES}

\subsection{Legume-based multiple cropping systems in soil fertility management}

Intercropping is one the most important multiple cropping systems (Gliessman, 1985:73). Intercropping occurs when two or more crops are grown in close proximity to one another. According to Chiputwa et al. (2011:6), the crops to be intercropped can be planted in different spatial patterns. In the case of strip intercropping, two or more crops are grown in different strips wide enough to be managed on their own but close to allow the different components to interact agronomically. With strip cropping, it is easier to control pests, legumes enhance soil fertility and the farmer can also increase the diversity of crops planted on the plot thereby reducing the risk of yield loss. Row intercropping occurs where both major crop and the intercrop planted in lines, making it easier to weed and harvest the crop. But at the time of seeding, labour requirements are high especially in the absence of mechanized planters. Relay intercropping refers to growing two or more crops with one of the crops being planted after the other crop has reached the reproductive growth phase. Relay intercropping reduces competition for resources because the second crop is planted after the first crop has reached its reproductive growth stage, but before it is ready for harvest. But on the other hand relay intercropping is only feasible when the growing season is longer to allow the second crop to reach maturity. Mixed intercropping is the growing of two or more crops without distinct rows. Here the seeds of both crops are sown together without any distinct row arrangement. Although mixed intercropping is easy, a farmer may face difficulty during weeding, fertilizer application and harvesting. Competition is also high because the plants are too close to one another.

Intercropping has been found to enhance sustainable intensification especially under lowlevel external input usage (World Bank, 2006). The effect of intercropping is more pronounced when legumes are incorporated into the mixture due to nitrogen fixation (Lithourgidis et al., 2011:396; Vandermeer, 1989:87). Legumes also enhance the accumulation of plant biomass on the soil surface leading to the build-up of organic matter and eventually increasing soil fertility (Snapp et al., 2002:160). Farmers also adopt intercropping systems because of other reasons. In a study conducted in South Western Uganda, farmers adopted intercropping for risk aversion and land scarcity not soil fertility improvement (Nuwagaba, Mangheni \& Tumuhairwe, 2001:8). Therefore, intercropping systems can play a crucial role in mitigating socio-economic constraints faced by smallholder farmers in agriculture. Intercropping becomes useful in terms of soil fertility management especially when nodulating legumes are incorporated in the mixture. The legume-intensified systems represent an affordable option for resource-poor smallholder farmers who cannot afford to purchase fertilizers (Snapp et al., 2002:166). 
S. Afr. J. Agric. Ext.

Vol. 44, No. 2, 2016: $195-215$

Ekepu \&

DOI: http://dx.doi.org/10.17159/2413-3221/2016/v44n2a421

Tirivanhu.

(Copyright)

In most West African countries, sorghum-legume intercrops are prevalent (Wortman et al, 2006:11) unlike countries like Uganda where sorghum is mainly grown as a sole crop (USAID, 2010:50). Unfortunately, when cereals are sole cropped without fertilizer use, soil mining and soil fertility decline is the end result. For this reason assessing adoption of cheap technologies like sorghum-legume intercrops for sustainable soil fertility management has been emphasized for resource-poor farmers. Most farmers have reported that legume intercrops reduce yield of cereals when part of the area is sown with legumes (Snapp et al., 2002: 168; Nuwagaba et al., 2001: 8) but the yield of the mixture when planted in appropriate patterns is greater than when either cereals or legumes are planted as single stands on the same piece of land (Woomer et al., 2004:88).

Crop rotation is another type of multiple cropping systems. Crop rotation can be defined as alternation of crops belonging to different families especially cereals and legumes on the same piece of land every year (Chomba as cited in Chiputwa et al., 2011:6). Legume rotations have been reported to diversify cropping systems and improve soil fertility management (Franke et al., 2014:29). In southern Africa, it has been reported that legume rotations increased maize yields by $10-78 \%$, but this is more profound when production is diversified into viny or shrubby-like legumes such as Mucuna pruriens and pigeon pea (Cajanus cajan) (Snapp et al., 2010:20841).

\subsection{Adoption of Technologies}

Increasing the speed of technology adoption is a key requirement for enhancing food security, agricultural productivity, economic growth and reduction of poverty in economically vulnerable communities (Ndiritu et al., 2014:118). Adoption has been defined differently by authors. Feder, Just \& Zilberman (1985:256) defined adoption as "the degree of use of a new technology in long-run equilibrium when the farmer has full information about the new technology and its potential". Wilkinson (1989) as cited in (Siziba, 2007:27) views adoption as an ongoing process occurring in a stepwise fashion. In fact, an early conceptualization of adoption of technologies as a process was coined by (Rogers, 1962) through the so called "Diffusion of Innovations" theory. According to Rogers (1995:20) adoption occurs through a process of five key stages namely; knowledge, persuasion, decision, implementation, and confirmation. Knowledge stage is where potential adopters need to learn about the new technology while persuasion refers to the stage where adopters have to be convinced to accept the new technology. Decision phase is when farmers decide to take up the technology. During Implementation the technology is put into practice and finally confirmation phase refers to the stage where the adopter has to reaffirm or reject his decision to adopt the technology. Various studies on agricultural adoption including (Mwangi et al., 2015:4; Mugwe, 2009:66; Moser and Barrett, 2003:1097; De Souza Filho et al., 1999:99) have often categorized farmers as adopters or non adopters. An adopter can simply be regarded as a person who consistently uses a technology.

Measurement of the rate of technology adoption can be done through different ways such as time needed for a particular group of people to adopt a technology, the number of technologies adopted when studying adoption of composite technologies or the percentage of technology adopters (Bonabana-Wabbi, 2002:25). Regarding the adoption of legume-based multiple cropping systems, the number of adopters can be useful in establishing the extent of adoption. Several factors influence the adoption of technologies and these can be categorized into biophysical, socio-economic, technology and institutional factors. Recent studies established that socio-economic factors have a significant effect on the adoption of soil 
S. Afr. J. Agric. Ext.

Vol. 44, No. 2, 2016: $195-215$

Ekepu \&

DOI: http://dx.doi.org/10.17159/2413-3221/2016/v44n2a421

Tirivanhu.

(Copyright)

fertility management practices (Mwase et al., 2015:148; Lambrecht et al., 2014:20; Mugwe et al., 2009:73). Once the biophysical environment has been fully understood, socio-economic factors and their interactions must be factored in the process of developing legume-based technologies (Ojiem et al., 2006:80).

Numerous household, economic and farm-related variables have been reported to influence the adoption of technologies (Jariko et al., 2011:194). The factors included in this study are; age of the respondent, farming experience, hired labour, farm size, gender, number of years in formal education, family size, number of extension contacts, off-farm income, credit and membership to a farmer group. Age has been reported to affect adoption of technologies negatively. Mbugua (2011:34) for example asserted that younger farmers adopt technologies faster because they are willing to try out new things. Age can also influence adoption positively because older farmers have accumulated a lot of knowledge through experimentation. Farming experience, a factor that is closely related to age was reported to have a negative influence on adoption of ISFM technologies in Western Kenya (Mugwe et al., 2009:70). In this study, however experience in sorghum production was hypothesized to have a positive influence on adoption because the farmer has gained knowledge regarding the type of cropping system that can maintain soil fertility. Hired labour is another factor which was expected to have positive influence on adoption of legume-based multiple cropping systems. This is because hired labour increases labour availability in the farmstead (Mugwe et al., 2009:70). Farm size is expected to have a positive influence because farmers with large land holdings are less risk averse, thus more likely to adopt legume-based multiple cropping systems. Gender is critical to the adoption of technologies. Males are hypothesized to easily adopt technologies in Uganda because they own and control resources and decision making on the farm. Number of years in formal education is another factor, which has been hypothesized to negatively affect technology adoption because highly educated farmers consider legume-based multiple cropping as a primitive way of maintaining soil fertility. Family size is another factor that affects adoption because it increases the availability of labour on the farm. The number of extension contacts influences adoption because extension is a source of information regarding good farming practices. Off-farm income for the farmer can provide extra financial resources to purchase legume seeds. Access to credit is also an important factor in adoption of technologies because farmers with adequate capital have leverage over financial constraints. Membership to farmer group was hypothesized to positively influence technology adoption because farmers in groups can be privileged to have access to technical information regarding legume-based multiple cropping.

\section{RESEARCH METHODOLOGY}

\subsection{The study area}

The study was carried out in Soroti district, eastern Uganda. Soroti district is bordered by Amuria in the North, Lake Kyoga and Kaberamaido in the West, Serere in the South and Ngora in East. The household population of the district was estimated to be 291,154 in 2014 (UBOS, 2014:20). Soroti district was selected as the study area since it is one of the leading producers of sorghum in Uganda and it has benefited from contract sorghum production arrangements with brewing companies including Nile Breweries Ltd. According to the Uganda survey on agriculture 2008/2009 summary report, Soroti district was found to be the leading producer of sorghum (UBOS, 2010:15). Data on the trends of sorghum production in Soroti district is scarce, but the general trends of Sorghum yields in Uganda are on a decline from about 14.573 hectograms per hectare in 2007 to about 8.543 hectograms per hectare in 2014 (Factfish, 2015). Sorghum was mainly grown for subsistence, but when the eagle lager 
S. Afr. J. Agric. Ext.

Vol. 44, No. 2, 2016: $195-215$

DOI: http://dx.doi.org/10.17159/2413-3221/2016/v44n2a421
Ekepu \&

Tirivanhu.

(Copyright)

project was launched in 2002, contracts between Nile Breweries ltd and smallholder farmers increased the acreage under sorghum due to guaranteed prices for farmers. The company also offers training programs and seed to farmers at reasonable prices.

Soroti district is situated at a lower altitude which makes it suitable for sorghum production, with a semi-arid-like climate. The district receives annual rainfall of about 1100-1200mm but rainfall is unreliable resulting in frequent floods and droughts. The soils are largely poor, shallow and light textured with sandy loam (Friis-Hansen, 2005:4). The farmers mostly practice mixed farming but crop production is dominated by annual crops. Other crops grown in Soroti district alongside sorghum include; cassava, sweet potatoes, groundnuts, cow pea, common beans and simsim. Market-oriented horticultural crops such as oranges, mangoes, pineapples and avocadoes also dominate the cropping sector (Semakula, 2011:10). Farmers also rear livestock including cattle, goats, sheep, pigs and poultry. Although farming is the key economic activity, income from agriculture remains very low due to low technological innovations. Political events of the late 1980s to early 1990s and early 2000s disrupted agricultural development in Soroti district as many government parastatals and producer cooperatives collapsed. Strengthening of local agricultural support institutions has thus been a challenge for agricultural activities in Soroti. Cattle rustling continue to reduce the number of animals to levels that are insufficient to sustain crop production. These factors have undermined agricultural development in the district. Although a number of new agricultural projects have been initiated by government and NGOs in the district, their impact is yet to be realized. Figure 1 shows the location of Soroti District. 


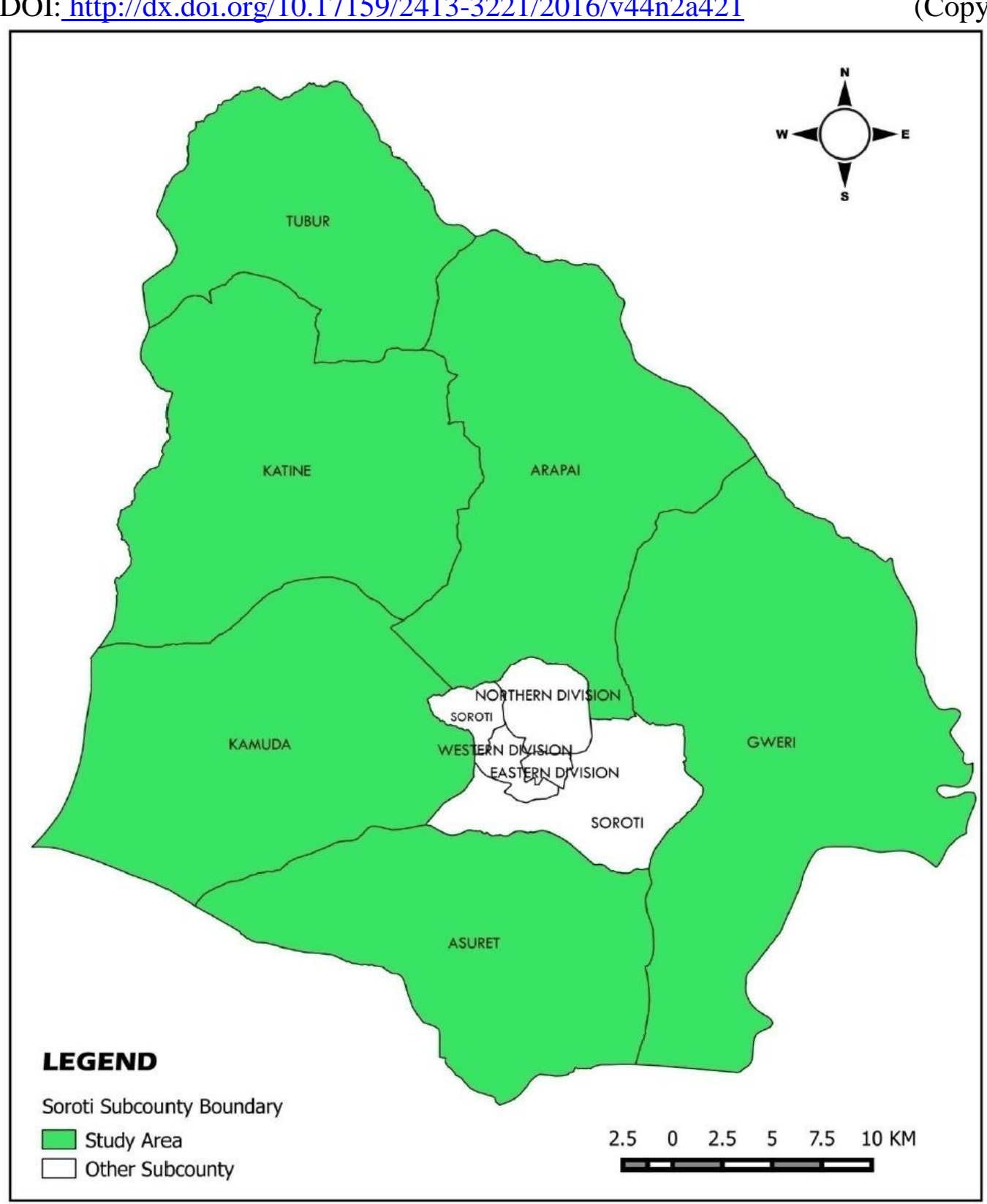

Figure 3: Location of Soroti District

\subsection{Sampling technique}

A multi-stage simple random sampling technique was employed for selecting respondents that took part in the survey. A list of 120 sorghum farmers was randomly selected and included in this study. Respondents were chosen from six sub-counties who were then be traced to their parishes and villages. The six sub-counties that were included in the study are; Asuret, Kamuda, Tubur, Katine, Arapai and Gweri sub-counties. These were selected since they are the main sorghum producing sub countries in Soroti. In each sub-county, two parishes were selected and in turn two villages were selected from each parish.

\subsection{Primary data collection methods}

Quantitative data was collected through face-to-face interviews using a structured questionnaire. Students from College of Agricultural and Environmental Sciences, Makerere 
S. Afr. J. Agric. Ext.

Vol. 44, No. 2, 2016: $195-215$

Ekepu \&

DOI: http://dx.doi.org/10.17159/2413-3221/2016/v44n2a421

Tirivanhu.

(Copyright)

University were trained as enumerators to administer questionnaires to the respondents. However, to capture farmers own views, open ended questions were also included in the survey instrument. The responses from the questionnaire were coded to make it easy to analyze using SPSS version 21.

Three Focus Group Discussions (FGDs) were also conducted to obtain a deeper understanding of socio-economic factors affecting adoption of legume-based multiple cropping among smallholder sorghum farmers in Soroti, Uganda. Each group had an average of 6 participants. The responses solicited from the participants were tape recorded and then transcribed for analysis. The data was analyzed using thematic analysis.

\subsection{Data analysis}

Descriptive statistics (frequencies and means) were estimated in order to summarize the findings of the study. Logistic regression analysis was performed to establish socio-economic factors that significantly affected the adoption of legume-based multiple cropping systems.

A logit model was used for analysis because the dependent variable is dichotomous as the respondents will be categorized into adopters and non-adopters. Adopters in this study are defined as those farmers who have adopted sorghum-legume intercropping or sorghumlegume rotations.

The logit model framework uses maximum likelihood method (Ali et al., 2007:949). This model is illustrated below;

$Q_{i k}=F\left(I_{i k}=e^{z i k} /\left(1+e^{z i k}\right)\right)$

For $Z_{i k}=X_{i k} \beta_{i k}$ and $-\infty<Z_{i k}<\infty$

Where $Q_{i k}$ is the dependent variable which is assigned a value of 1 for adoption of a legumebased multiple cropping system by the sorghum farmer and 0 for otherwise. $X_{i k}$ Shows a matrix of predictor variables related to the adoption of a legume-based multiple cropping system by a sorghum farmer $i$ and $\beta_{i k}$ are vectors of parameters that were estimated. $I_{i k}$ is the implicit variable indexing adoption, whereas $\mathrm{F}\left(I_{i k}\right)$ is the probability that the $i^{\text {th }}$ sorghum farmer adopts a legume-based multiple cropping system and 0 otherwise.

$\mathrm{X}$ is therefore assumed as to be a function of the list of socio-economic factors.

The adoption decision can, therefore, be specified as;

$Y=(X, \epsilon)$

Where $\in$ is the error term with a logistic distribution

The independent variables of interest include; age of the respondent, farming experience, family size, years in formal education, number of extension contacts, hired labor, off-farm income, credit, gender and membership to farmer group.

Empirical model specification

The effect a given set of explanatory variables has on adoption of legume-based multiple cropping systems can be represented by the following expression;

Adoption $=\mathrm{f}\left(\mathrm{x}_{1} \mathrm{x}_{2} \mathrm{x}_{3} \mathrm{X}_{4} \ldots \ldots \ldots \mathrm{x}_{\mathrm{n}}\right)$

$Y=\beta_{0}+\beta_{1} X_{1}+\beta_{2} X_{2}+\beta_{3} X_{3}+\cdots \beta_{11} X_{11}+\epsilon$ 
S. Afr. J. Agric. Ext.

Vol. 44, No. 2, 2016: $195-215$

DOI: http://dx.doi.org/10.17159/2413-3221/2016/v44n2a421
Ekepu \&

Tirivanhu.

(Copyright)

Where $\mathrm{Y}=\mathrm{a}$ dichotomous response variable such that, $\mathrm{Y}=1$, if sorghum farmers adopt legumebased multiple cropping systems and 0 , if farmers do not.

$\mathrm{X}_{1}=$ age of the respondent

$\mathrm{X}_{2}=$ Farming experience

$\mathrm{X}_{3}=$ Family size

$\mathrm{X}_{4}=$ Farm size

$\mathrm{X}_{5}=$ years in formal education

$\mathrm{X}_{6}=$ number of extension contacts

$\mathrm{X}_{7}=$ Hired labour

$\mathrm{X}_{8}=$ off-farm income

$\mathrm{X}_{9}=$ credit

$\mathrm{X}_{10}=$ Gender

$\mathrm{X}_{11}=$ Membership to farmer group

$\epsilon=$ Error term which is usually indicated at zero mean and variance.

$\beta_{0}$ is a constant

$\beta_{1}, \beta_{2}, \ldots \ldots \beta_{11}$ are coefficients of the independent variables. 
S. Afr. J. Agric. Ext.

Vol. 44, No. 2, 2016: $195-215$

DOI: http://dx.doi.org/10.17159/2413-3221/2016/v44n2a421

The coefficients of the regression model were estimated using maximum likelihood estimation (MLE) method and results of the logit coefficients were presented and discussed.

Table 1: Measurement of variables

\begin{tabular}{|l|l|l|l|}
\hline Observations & Variable description & $\begin{array}{l}\text { Variable } \\
\text { type }\end{array}$ & $\begin{array}{l}\text { Expected } \\
\text { sign }\end{array}$ \\
\hline Dependent variables & & & \\
\hline Sorghum-legume rotations & Whether farmers adopt sorghum-legume rotations or not & Binary & NA \\
\hline Sorghum-legume intercropping & Whether farmers adopt sorghum-legume intercropping or not & Binary & NA \\
\hline Independent variables & & & \\
\hline Age of the respondent & Number of years the respondent has lived & continuous & + \\
\hline Farming experience & Number of years the respondent has been growing sorghum & continuous & + \\
\hline Family size & Total number of people in the respondent's household & continuous & + \\
\hline Farm size & Size of the farm in acres & continuous & + \\
\hline Years in formal education & Number of years the respondent spent in formal education & continuous & - \\
\hline Number of extension contacts & Number of contacts with extension staff in 2015 & continuous & + \\
\hline Hired Labour & Whether farm labour is hired or not & categorical & + \\
\hline Off-farm income & $\begin{array}{l}\text { Whether the household has a side business so as to earn extra } \\
\text { income or not }\end{array}$ & categorical & + \\
\hline Credit & Whether the farmer borrowed money in 2015 or not & categorical & + \\
\hline Gender & Whether the respondent is male or female & categorical & + \\
\hline Membership to farmer group & Whether the respondent belongs to a farmer group or not & categorical & + \\
\hline
\end{tabular}


S. Afr. J. Agric. Ext.

Vol. 44, No. 2, 2016: $195-215$

DOI: http://dx.doi.org/10.17159/2413-3221/2016/v44n2a421

4. RESULTS

4.1 Demographic characteristics of the respondents
Ekepu \&

Tirivanhu.

(Copyright)

From the SPSS output, $55 \%$ of the respondents in the study were female while $45 \%$ were male. In terms of marital status, $2.5 \%$ were single, $73.3 \%$ were married, $5 \%$ were divorced, $15.8 \%$ were widowed and $3.3 \%$ were separated. Whereas on the basis of education, on average respondents had completed at least 5 years in formal education. The average number of people living in each household was 8 .

\subsection{Extent of adoption of legume-based multiple cropping systems among smallholder sorghum farmers}

Results indicated that $51.7 \%$ of the respondents had planted a legume crop in the 2014 season before sorghum was planted in 2015 while $48.7 \%$ of the respondents had not rotated sorghum and legumes. On the other hand, only $8.3 \%$ of the respondents had intercropped sorghum with legumes in 2015 while $91.7 \%$ had not intercropped sorghum with legumes.

\subsection{Logistic regression model estimates}

Logistic regression results (Table 2) indicate that only the number of extension contacts had a positively significant $(\mathrm{p}<0.05)$ effect on adoption of sorghum-legume rotations in Soroti district. Although factors like age, farming experience, family size, farm size, years in formal education, hired labour, off-farm income, credit, gender and membership to farmer group were hypothesized to influence adoption, they had no significant effect adoption of sorghumlegume rotations. The model also explained 16.7\% (Cox and Snell R Square) and 22.3\% (Nagelkerke R Square) of the variance in adoption of sorghum-legume rotations and correctly classified $71.7 \%$ of the cases.

Family size however had a significant $(\mathrm{p}<0.05)$ but negative effect on adoption of sorghumlegume intercropping. Age, farming experience, farm size, years in formal education, number of extension contacts, hired labour, off-farm income, credit, gender and membership to farmer group, on the other hand had no significant effect on the adoption of sorghum legume intercropping. The model explained 16.3\% (Cox and Snell R Square) and 37.4\% (Nagelkerke $\mathrm{R}$ Square) of the variance in the adoption of sorghum-legume intercropping and correctly predicted $94.2 \%$ of the cases. 
Table 2: Logit regression of socio-economic factors influencing adoption of legume-based multiple cropping systems among smallholder sorghum farmers in Soroti, Uganda

\begin{tabular}{|l|l|l|}
\hline \multirow{2}{*}{ Parameters (X's) } & $\begin{array}{l}\text { Legume-based multiple cropping systems among sorghum } \\
\text { farmers }\end{array}$ \\
\cline { 2 - 3 } & Sorghum-legume rotations & $\begin{array}{l}\text { Sorghum-legume } \\
\text { intercropping }\end{array}$ \\
\hline Age & $0.030(\mathrm{~ns})$ & $0.002(\mathrm{~ns})$ \\
\hline Farming experience & $-0.041(\mathrm{~ns})$ & $-0.028(\mathrm{~ns})$ \\
\hline Family size & $-0.053(\mathrm{~ns})$ & $-0.690(0.007)$ \\
\hline Farm size & $0.054(\mathrm{~ns})$ & $0.354(\mathrm{~ns})$ \\
\hline Years in formal education & $0.076(\mathrm{~ns})$ & $0.015(\mathrm{~ns})$ \\
\hline $\begin{array}{l}\text { Number of extension } \\
\text { contacts }\end{array}$ & $0.171(0.034)$ & $0.076(\mathrm{~ns})$ \\
\hline Hired labour & $-0.756(\mathrm{~ns})$ & $0.261(\mathrm{~ns})$ \\
\hline Off-farm income & $-0.757(\mathrm{~ns})$ & $0.680(\mathrm{~ns})$ \\
\hline Credit & $0.636(\mathrm{~ns})$ & $-1.042(\mathrm{~ns})$ \\
\hline Gender & $0.372(\mathrm{~ns})$ & $-1.335(\mathrm{~ns})$ \\
\hline Membership to farmer group & $0.407(\mathrm{~ns})$ & $-0.633(\mathrm{~ns})$ \\
\hline Constant & $-1.007(\mathrm{~ns})$ & $1.156(\mathrm{~ns})$ \\
\hline-2 loglikelihood & 144.283 & 47.425 \\
\hline Cox and Snell R Square & 0.167 & 0.163 \\
\hline Nagelkerke R Square & 0.223 & 0.374 \\
\hline \% correct predicted & 71.7 & 94.2 \\
\hline Sig &
\end{tabular}

Sig=5\% level of significance; ns= not significant

\section{DISCUSSION}

5.1 Adoption of legume-based multiple cropping systems among smallholder sorghum farmers.

The study showed that adoption of sorghum-legume rotations was higher than sorghumlegume intercropping among smallholder farmers in Soroti district. Literature shows that crop rotations have a higher potential to increase biomass production and enhance soil carbon content (Palm et al., 2014:89; West and Post, 2002:1930). Higher yields of cereals following a legume crop have also been strongly attributed to increased levels of mineral nitrogen in the soil (Alvey et al., 2001:45). The reasons farmers gave for increased adoption of sorghumlegume rotations in Soroti are given in the following quotations from a focus group discussion that was held on 8 December, 2015.

For me rotating sorghum with legumes gives high sorghum yields because the sorghum crop planted next in the rotation will benefit from the food that was left in the soil from the previous legume crop.

When I harvest a legume crop from my garden, the crop residues that remain on the soil surface can be buried underground and thereby improve soil fertility for the next crop in the rotation.

The low adoption of sorghum-legume intercropping has been associated with reduced yield of sorghum in the intercropping system compared to sole cropping because sorghum is taken 
S. Afr. J. Agric. Ext.

Vol. 44, No. 2, 2016: $195-215$

Ekepu \&

DOI: http://dx.doi.org/10.17159/2413-3221/2016/v44n2a421

Tirivanhu.

(Copyright)

as an important cash crop for the farmers in Soroti district. Some of the reasons for the low adoption of sorghum-legume intercropping are presented in the following quotations from the focus group discussion with smallholder sorghum farmers that was held on 8 December 2015.

Intercropping sorghum and legumes will lead to the production of small heads of sorghum and even the legumes will not yield properly because sorghum will compete with the legumes for sunshine.

Mixing legumes and sorghum in the same garden will lead to a low yield of sorghum because legume plants can wind around the sorghum crop, therefore, hindering the sorghum crop from growing properly.

\subsection{Socio-economic factors influencing adoption of legume-based multiple cropping systems among smallholder sorghum farmers.}

The study focused on determining socio-economic factors that significantly affected the adoption of legume-based multiple cropping systems among smallholder sorghum farmers in Soroti district. This is because the decision at to adopt technologies at individual farmer level is always determined by several factors (Mwangi et al., 2015:1; Kebede et al., 1990:27). Age had no significant effect on adoption of either sorghum-legume rotations or sorghum-legume intercropping in Soroti district. According to Mugwe et al. (2012:1791), age is regarded as a primary dormant attribute in technology adoption decisions. Some authors including (Mwangi et al., 2015:7) however reported that age had a mixed effect on the adoption of cover crops in Kenya. Other studies have found age to have a positive influence on adoption of sorghum in Burkina Faso (Adesina \& Baidu-Forson, 1995:5) and Integrated Soil Fertility Management in Central Kenya (Mugwe et al., 2012:1791). In Soroti district, age was insignificant because the systems of sorghum production that are practiced by farmers usually cut across all age groups. Farming experience, a factor that is closely related to age also had no significant effect on adoption of sorghum-legume rotations or sorghum-legume intercropping.

Family size had a significant effect on adoption of sorghum-legume intercropping but no significant effect on adoption of sorghum-legume rotations. Family size is a factor that is believed to determine the availability of labour on the farm. But for this study family size had a negative influence on adoption of sorghum-legume intercropping in Soroti district, which was not expected. Therefore, an increase in family size will decrease the chance of farmers adopting sorghum-legume intercropping. One of the reasons could be that intercropping increases labour use efficiency on the farm, but increased family size may eventually lead to diminishing marginal returns as too much of labour input leads to decline in profit to the farmer. For that reason big family sizes react by not adopting sorghum-legume intercropping systems.

Although farm size did not have a significant effect on adoption of either sorghum-legume rotations or sorghum-legume intercropping, it showed a positive relationship with the adoption of sorghum-legume rotations and sorghum-legume intercropping as expected. Previous studies on technology adoption have found farm size to have a positive effect (Everlyne, Agnes and David, 2013: 297) and negative effect (Yaron, Dinar and Voet, 1992:361). Abara \& Singh (1993:289) acknowledge the existence of differences in technology adoption between large and small farms. Small farms have been argued to have high fixed costs thereby hindering technology adoption. 
Education is another factor that has a bearing on adoption of agricultural technologies. Some technologies are more knowledge-intensive than other technologies. For this study, the number of years in formal education had a positive influence on the adoption of both sorghum-legume rotations and sorghum-legume intercropping in Soroti district which was not expected. The results of this study are also consistent with findings by (Chiputwa et al., 2011:15) who reported a positive association between education and adoption of crop rotation in Zimbabwe. A study by Jera \& Ajayi (2008:388) however found education to have a negative influence on adoption tree-based fodder technologies in Zimbabwe, although not significant at $5 \%$ level of significance.

The number of extension contacts had a significantly positive influence on the adoption of sorghum-legume rotations but not significantly positive relationship with the adoption of sorghum-legume intercropping. Good extension contacts for the farmers generally influences the level of technology dissemination and adoption (Yudelman, Ratta \& Nygaard, 1998:42). Studies analyzing this variable have shown a positive relationship with the adoption of technologies (Mugwe et al., 2012:1792).

Hired labour had a negative relationship with adoption of sorghum-legume rotations and a positive relationship with the adoption of sorghum-legume intercropping although both values were not statistically significant ( $\mathrm{p}>0.05$ ). Findings by D'Souza, Cyphers \& Phipps, (1993:162) showed that hired labour had no significant effect on adoption of sustainable agriculture practices in West Virginia. Chirwa (2005:6) also found hired labour to have no significant $(p>0.05)$ effect on adoption.

Off-farm income had a negative relationship with the adoption of sorghum-legume rotations but a positive relationship with the adoption of sorghum-legume intercropping, although statistically insignificant at $5 \%$ level of significance. The negative relationship between offfarm income and adoption of sorghum-legume rotations was not expected however the positive correlation with adoption of sorghum-legume intercropping is associated with additional capital during the beginning of the planting season hence making it possible for the farmer to afford more than two types of crop seed that can be planted on the same piece of land. Chirwa (2005:8) found a positive relationship between non-farm sources of income and adoption of inorganic fertilizers in Malawi.

Access to credit is another factor that influences adoption of agricultural technologies. The credit variable had a positive correlation with the adoption of sorghum -legume rotations but a negative relationship with the adoption of sorghum-legume intercropping, however the relationships in both cases were insignificant at 5\% level of significance. Credit can be a factor that increases the availability of capital on the farm to purchase legume and sorghum seeds. Feder et al. (1985:278) reported that access to credit did not have a significant effect on adoption of "scale-neutral technologies", but the results on adoption of different technologies in developing countries generally gave mixed results. Intercropping systems have been associated with farmers having small land holdings and such farmers are unwilling to invest in capital intensive technologies because it leads to high fixed costs. Therefore, adoption of sorghum-legume intercropping had a negative connection with the credit variable.

Gender showed a positive relationship with the adoption of sorghum-legume rotations but negative association with the adoption of sorghum-legume intercropping in Soroti district, but 
S. Afr. J. Agric. Ext.

Vol. 44, No. 2, 2016: $195-215$

Ekepu \&

DOI: http://dx.doi.org/10.17159/2413-3221/2016/v44n2a421

Tirivanhu.

(Copyright)

the findings were insignificant. There are mixed facts regarding the effect of gender on technology adoption in most recent findings (Mugwe et al., 2012:1792). For example Mwangi et al. (2015:5) reported a positive relationship between gender and adoption of cover crops in Kenya whereas (Morris \& Doss, 1999:5) found gender to be less significant in adoption of improved maize technology in Ghana.

Membership to farmer group had no significant ( $\mathrm{p}>0.05)$ effect on adoption of sorghumlegume rotations or sorghum-legume intercropping in Soroti district. Regarding the direction of the association, there was a positive relationship between membership to farmer group and adoption of sorghum-legume rotations while the relationship between membership to farmer group and sorghum-legume intercropping was negative. This could be related to the fact that most group extension trainings have advocated farmers to practice more crop rotations rather than intercrop sorghum in Soroti. Kassie et al. (2013:528) asserted that membership to a farmer group increases a farmer's social capital and thereby facilitating the exchange of relevant agricultural information among farmers.

From the findings of focus group discussions, another factor that emerged to be influencing adoption of legume technologies is an inadequate market for legume crops in Soroti. Similar findings were reported by (Snapp et al., 2002:159) who found adoption of legume crops in Malawi to be highly linked to the availability of market. An example of a quotation from a focus group discussion in Soroti with smallholder farmers that was held on the $11^{\text {th }}$ December 2015 is as follows;

Let me give an example of cowpeas, I grow them only for home consumption these days because when you plant a lot of cowpeas, you cannot get good market and, therefore, end up with little profit.

\section{CONCLUSION AND RECOMMENDATIONS}

This study offers insights to policy makers, researchers and extension workers regarding the advancement of suitable intervention strategies for smallholder farmers. Although many studies have proven the benefits of legumes in sorghum production systems, it is vital that policy makers realize the effect various socio economic factors such as family size and extension contacts influence farmer's decision to adopt sorghum-legume rotations or sorghum-legume intercropping.

From the findings of this study, there are no noticeable common factors that affect the farmers decision to adopt sorghum-legume rotations or sorghum-legume intercropping in Soroti district. Each of these technologies is distinctively affected by different factors and this means that development actors should target those farmers that have appropriate socioeconomic attributes that promote adoption of a given technology.

The empirical results have demonstrated that family size had a negatively significant influence on adoption of sorghum-legume intercropping but insignificant on adoption of sorghum-legume rotations. The implication is that household demographic information for different farming regions needs to be up to date and readily accessible to development agencies to target adoption of agriculture technologies. On the other hand, the positive influence of extension contacts on adoption of sorghum-legume rotations means the provision of more extension training to smallholder farmers by development organizations is needed because extension is a major source of technical information regarding different technologies. 
S. Afr. J. Agric. Ext.

Vol. 44, No. 2, 2016: $195-215$

Ekepu \&

DOI: http://dx.doi.org/10.17159/2413-3221/2016/v44n2a421

Tirivanhu.

(Copyright)

Increasing funding to extension agencies and facilitation of extension workers will lead to the penetration of extension services into the rural communities.

The study, therefore, recommends that strengthening value chains for legume crops can enhance adoption of legume-based multiple cropping systems. Also, more studies should be carried out to evaluate other factors controlling adoption; cost-benefit analysis of adoption of legume-based multiple cropping systems to eliminate any doubt for smallholder farmers likely to adopt legume-based multiple cropping systems and good policies be implemented to increase knowledge and skills, reinforce farmers' ability to cover associated costs and eradicate market barriers to adoption of legume-based multiple cropping systems. The implication of this study to agricultural extension service delivery is that extension agents need to focus their attention on disseminating technologies that are accepted and feasible in farming communities. In this study, adoption of sorghum-legume rotations by smallholder farmers showed a positive relationship with the number of extensions contacts attended by farmers. Therefore, more extension programs and messages should be geared towards promoting legume rotations as an alternative to soil fertility management.

\section{REFERENCES}

AATF, 2011. Feasibility study on striga control in sorghum. Nairobi, African Agricultural Technology Foundation (AATF). Available [ONLINE] at; http://aatfafrica.org/userfiles/Striga-in-Sorghum.pdf [Accessed 20th September 2015]

ABARA, I. O. \& SINGH, S. 1993. Ethics and biases in technology adoption: The small-firm argument. Technol Forecast Soc Change, 43(3), pp.289-300.

ADESINA, A. A. \& BAIDU-FORSON, J. 1995. Farmers' perceptions and adoption of new agricultural technology: evidence from analysis in Burkina Faso and Guinea, West Africa. Agr. Econ., 13(1), pp.1-9.

ALEXANDRATOS, N. \& BRUINSMA, J. 2012. World agriculture towards 2030/2050: the 2012 revision. ESA Working paper No. 12-03. Rome, FAO. [ONLINE] Available at: http://www.fao.org/docrep/016/ap106e/ap106e.pdf [Accessed 11th August, 2015]

ALI, L., MANGHENI, N. M., SANGINGA, P. C., DELVE, R. J., MASTIKO, F. \& MIIRO, R. 2007. Social capital and adoption of soil fertility management technologies in Tororo district, Uganda. In Advances in Integrated Soil Fertility Management in sub-Saharan Africa: Challenges and Opportunities (pp. 947-954). Springer Netherlands

ALVEY, S., BAGAYOKO, M., NEUMANN, G. \& BUERKERT, A. 2001. Cereal/legume rotations affect chemical properties and biological activities in two West African soils. Plant Soil, 231(1), pp.45-54.

BONABANA-WABBI, J. 2002. Assessing factors affecting adoption of agricultural technologies: The case of integrated pest management (IPM) in Kumi district, Eastern Uganda. Doctoral dissertation, Virginia Polytechnic Institute and State University

CHIPUTWA, B., LANGYINTUO, A. S. \& WALL, P. 2011. Adoption of conservation agriculture technologies by smallholder farmers in the Shamva District of Zimbabwe: A Tobit application. In Paper accepted for the 2011 meeting of the Southern Agricultural Economics Association (SAEA), Texas, USA.

CHIRWA, E. W. 2005. Adoption of fertiliser and hybrid seeds by smallholder maize farmers in Southern Malawi. Devel Southern Africa, 22(1), pp.1-12

D'SOUZA, G., CYPHERS, D. \& PHIPPS, T. 1993. Factors affecting the adoption of sustainable agricultural practices. Agr. Resource Econ. Rev, 22(2), pp.159-165. 
S. Afr. J. Agric. Ext.

Vol. 44, No. 2, 2016: $195-215$

Ekepu \&

Tirivanhu.

DOI: http://dx.doi.org/10.17159/2413-3221/2016/v44n2a421

(Copyright)

DE SOUZA FILHO, H. M., YOUNG, T. \& BURTON, M. P. 1999. Factors influencing the adoption of sustainable agricultural technologies: evidence from the State of Espírito Santo, Brazil. Technol Forecast Soc Change, 60(2), 97-112.

EBANYAT, P., DE RIDDER, N., DE JAGER, A., DELVE, R. J., BEKUNDA, M. A. \& GILLER, K. E. 2010. Drivers of land use change and household determinants of sustainability in smallholder farming systems of Eastern Uganda. Popul Environ, 31(6), 474-506.

EBIYAU, J., ARACH, T. \& SERUNJOGI, L. K. 2005.Commercialization of sorghum in Uganda.In African Crop Science Conference Proceedings.Vol. 7, No. pt. 2 of 3, pp. 695696

ESCOBAR, J. C., LORA, E. S., VENTURINI, O. J., YÁÑEZ, E. E., CASTILlO, E. F. \& ALMAZAN, O. 2009. Biofuels: environment, technology and food security. Renew Sust Energ Rev, 13(6), 1275-1287

EVERLYNE, A. C., AGNES, N. O. \& DAVID, A. M. 2013. Socio-Economic Factors Influencing Adoption of Energy-Saving Technologies among Smallholder Farmers: The Case of West Pokot County, Kenya. IJAMAD, 3(4), pp.289-301.

FACTFISH, 2015. Uganda: Sorghum yield (hectogram per hectare). Available [ONLINE] at: http://www.factfish.com/statistic-country/uganda/sorghum,\%20yield $\quad\left[\right.$ Accessed $10^{\text {th }}$ November, 2015]

FEDER, G., JUST, R. E. \& ZILBERMAN, D. 1985. Adoption of agricultural innovations in developing countries: A survey. Econ. Devel. Cult. Change, 255-298.

FRIIS-HANSEN, E. 2005. Agricultural development among poor farmers in Soroti District, Uganda. Impact assessment of agricultural technology, farmer empowerment and changes in opportunity structures. In Impact Assessment Workshop at CYMMYT (Vol. 19, p. 21)

FUGLIE, K., \& RADA, N. 2013. Resources, Policies, and Agricultural Productivity in SubSaharan Africa. USDA-ERS Economic Research Report, (145).

GEARY, J. 2009. The cost-benefit analysis of beer. [ONLINE] Available at: http://www.jamesgeary.com/assets/2009-09_Ethical_Corp_berr.pdf [Accessed 15th August, 2015]

GLIESSMAN, S. R. 1985. Multiple cropping systems: A basis for developing an alternative agriculture. NJ: Princeton University.

JERA, R. \& AJAYI, O. C. 2008. Logistic modelling of smallholder livestock farmers' adoption of tree-based fodder technology in Zimbabwe. Agrekon,47(3), pp.379-392.

KAIZZI, K. C., BYALEBEKA, J., SEMALULU, O., ALOU, I. N., ZIMWANGUYIZZA, W., NANSAMBA, A. \& WORTMANN, C. S. 2012. Optimizing smallholder returns to fertilizer use: Bean, soybean and groundnut. Field Crops Res., 127, 109-119

KASSIE, M., JALETA, M., SHIFERAW, B., MMBANDO, F. \& MEKURIA, M., 2013. Adoption of interrelated sustainable agricultural practices in smallholder systems: Evidence from rural Tanzania. Technological forecasting and social change, 80(3), pp.525-540

KEBEDE, Y., GUNJAL, K. \& COFFIN, G. 1990. Adoption of new technologies in Ethiopian agriculture: The case of Tegulet-Bulga district Shoa province. Agr. Econ., 4(1), pp.2743.

LAMBRECHT, I., VANLAUWE, B. \& MAERTENS, M. 2016. Integrated soil fertility management: from concept to practice in Eastern DR Congo. Int J Agr Sustain 14(1), pp. $100-118$

LITHOURGIDIS, A. S., DORDAS, C. A., DAMAlAS, C. A. \& VLACHOSTERGIOS, D. 2011. Annual intercrops: an alternative pathway for sustainable agriculture. 
S. Afr. J. Agric. Ext.

Vol. 44, No. 2, 2016: $195-215$

Ekepu \&

DOI: http://dx.doi.org/10.17159/2413-3221/2016/v44n2a421

Tirivanhu.

(Copyright)

MARTIN, A. 2008. Fuel choices, food crises and finger-pointing. The New York Times, 15, 2008

MBOGO, G. 2013. Impact of local sourcing initiatives: a case of Nile Breweries Ltd (SABMiller) sorghum and malting barley programmes in Uganda. [ONLINE] Available at: $\quad$ http://www.ibdafrica.co.za/wp-content/uploads/2013/05/Mbogo-manuscript.pdf [Accessed 13th April, 2015]

MBUGUA, F. 2011. An analysis of factors influencing adoption of the recommended maize technology's package in Makuyu Division, Murang'a South District, Kenya. Doctoral dissertation, Kenyatta University.

MITARU, B. N., MGONJA, M. A., RWOMUSHANA, I. \& OPIO, F. 2012. Integrated sorghum and millet sector for increased economic growth and improved livelihoods in Eastern and Central Africa. Proceedings of the ECARSAM stakeholders' conference 2021 November 2006, Dar es Salaam, Tanzania.

MORRIS, M. L. \& DOSS, C. R. 1999. How does gender affect the adoption of agricultural innovations? The case of improved maize technology in Ghana. In annual meeting of the American Agricultural Economics Association, Nashville, August (pp. 8-11)

MOSER, C. M. \& BARRETT, C. B. 2003. The disappointing adoption dynamics of a yieldincreasing, low external-input technology: the case of SRI in Madagascar. Agric. Sys., 76(3), 1085-1100..

MUGWE, J., MUGENDI, D., MUCHERU-MUNA, M., MERCKX, R., CHIANU, J. \& VANLAUWE, B. 2009. Determinants of the decision to adopt integrated soil fertility management practices by smallholder farmers in the central highlands of Kenya. Exp. Agric., 45(01), 61-75.

MUGWE, J. N., MAIRURA, F., KIMARU, S. W., MUCHERU-MUNA, M. \& MUGENDI, D. N. 2012. Determinants of adoption and utilisation of integrated soil fertility management by small holders in Central Kenya. Third RUFORUM Biennial Meeting 2428 September, 2012, Entebbe, Uganda.

MUTIBO, C. 2012. Factors Affecting a Farmer's Willingness to Adopt Intercropping in Cotton: A Case Study of Farmers in Magoye, Zambia. Available [ONLINE] at: https://www.icac.org/wp-content/uploads/2012/09/Zambia_Intercropping1.pdf (Accessed 1st October, 2015)

MWANGI, H. W., KIHURANI, A. W., WESONGA, J. M., ARIGA, E. S. \& KANAMPIU, F. 2015. Factors influencing adoption of cover crops for weed management in Machakos and Makueni counties of Kenya. Eur J Agron, 69, 1-9.

MWASE, W., SEFASI, A., NJOLOMA, J., NYOKA, B. I., MANDUWA, D. \& NYAIKA, J. 2015. Factors Affecting Adoption of Agroforestry and Evergreen Agriculture in Southern Africa. Environment and Natural Resources Research, 5(2), pp148-157.

NDIRITU, S. W., KASSIE, M. \& SHIFERAW, B. 2014. Are there systematic gender differences in the adoption of sustainable agricultural intensification practices? Evidence from Kenya. Food Pol., 49, 117-127.

NUWAGABA, J. M., MANGHENI, M. N. \& TUMUHAIRWE, J. K. 2015 Farmers' Evaluation Of Soil Management Practices Used In Mbarara District, South Western Uganda. Available [ONLINE] at: http://archive.unu.edu/env/plec/clusters/Eastafrica/nov2001/Nuwagaba.pdf [Accessed 20th September, 2015]

OJIEM, J. O., FRANKE, A. C., VANLAUWE, B., DE RIDDER, N. \& GILLER, K. E. 2014. Benefits of legume-maize rotations: Assessing the impact of diversity on the productivity of smallholders in Western Kenya. Field Crops Res., 168, 75-85. 
S. Afr. J. Agric. Ext.

Vol. 44, No. 2, 2016: $195-215$

Ekepu \&

DOI: http://dx.doi.org/10.17159/2413-3221/2016/v44n2a421

Tirivanhu.

(Copyright)

ORIOLA, E. O. \& BAMIDELE, I. O. 2012. Impact of cropping systems on soil properties in derived ecological zone of Kwara State, Nigeria. Con. J. Envtal. Stds, 7:34-41 Oxford University Press.

PALM, C., BLANCO-CANQUI, H., DECLERCK, F., GATERE, L. \& GRACE, P. 2014. Conservation agriculture and ecosystem services: an overview. Agric Ecosyst Environ, 187, pp.87-105.

RAO, M. R., REGO, T. J. \& WILLEY, R. W. 1987. Response of cereals to nitrogen in sole cropping and intercropping with different legumes. Plant Soil, 101(2), 167-177.

ROGERS, E. M. 1962. Diffusion of Innovations. Free Press, New York, NY.

ROGERS, E. M. 1995. Diffusion of innovations. Free Press, New York, NY.

SABMILLER. 2014. SABMiller annual report 2014. Available [ONLINE] at: http://www.sabmiller.com/docs/default-source/investor-

documents/reports/2014/financial-reports/annual-report-2014.pdf?sfvrsn=10 [Accessed $1^{\text {st }}$ April, 2016]

SIZIBA, S. 2007. Assessing the adoption of conservation agriculture in Zimbabwe's smallholder sector. Unpublished PHD thesis. University of Hohenheim

SNAPP, S. S., BLACKIE, M. J., GILBERT, R. A., BEZNER-KERR, R. \& KANYAMAPHIRI, G. Y. 2010. Biodiversity can support a greener revolution in Africa. Proceedings of the National Academy of Sciences, 107(48), 20840-20845

SNAPP, S. S., ROHRBACH, D. D., SIMTOWE, F. \& FREEMAN, H. A. 2002. Sustainable soil management options for Malawi: can smallholder farmers grow more legumes? Agric Ecosyst Environ, 91(1), 159-174.

SSEMAKULA, E. 2011. Local Government Councils' Performance and Public Service Delivery in Uganda: Soroti District Local Government Council Score-Card Report 2009/10. ACODE Policy Research Series, No. 55, 2011. Kampala.

TURINAWE, A., MUGISHA, J. \& DRAKE, L. 2015. Soil and water conservation agriculture in subsistence systems: Determinants of adoption in south western Uganda. $J$. Soil Water Conserv , 70(2), 133-142.

UBOS, 2010. Uganda Bureau of Statistics: summary report on Uganda census of agriculture 2008/2009. [ONLINE] Available at:

http://www.ubos.org/onlinefiles/uploads/ubos/pdf\%20documents/UCASummary.pdf [Accessed 25th April, 2015]

UBOS, 2014. Uganda Bureau of Statistics 2015 statistical abstract. [ONLINE] Available at: http://www.ubos.org/onlinefiles/uploads/ubos/statistical_abstracts/Statistical\%20Abstract \%202015.pdf (Accessed $2^{\text {nd }}$ April, 2016)

UBOS, 2014: Uganda national population and housing census: provisional results. Available [ONLINE]

at: http://www.ubos.org/onlinefiles/uploads/ubos/NPHC/NPHC\%202014\%20PROVISION AL\%20RESULTS\%20REPORT.pdf [Accessed $10^{\text {th }}$ November, 2015]

UNITED NATIONS GLOBAL COMPACT. 2012. Scaling up global food security and sustainable agriculture. [ONLINE] Available at:

http://www.circleofblue.org/waternews/wpcontent/uploads/2012/07/UN-Global-

Compact-Scaling-Up-Global-Food-Security-and-Sustainable-Agriculture.pdf [Accessed 6th November, 2015]

USAID, 2010. Market assessment and baseline survey of staple foods. Country reportUganda. [ONLINE] Available at: http://pdf.usaid.gov/pdf_docs/Pnadw642.pdf [Accessed 11th August, 2015]

VANDERMEER, J. 1989. The ecology of intercropping. Cambridge: Cambridge University Press 
S. Afr. J. Agric. Ext.

Vol. 44, No. 2, 2016: $195-215$

DOI: http://dx.doi.org/10.17159/2413-3221/2016/v44n2a421
Ekepu \&

Tirivanhu. (Copyright)

WEST, T. O. \& POST, W. M. 2002. Soil organic carbon sequestration rates by tillage and crop rotation. Soil Sci. Soc. Am. J, 66(6), pp.1930-1946.

WONIALA, J. \& NYOMBI, K. 2014. Soil fertility management by smallholder farmers and the impact on soil chemical properties in Sironko district, Uganda. Research Journal of Agriculture and Forestry Sciences.

WOOMER, P. L., LAN'GAT, M. \& TUNGANI, J. O. 2004. Innovative maize-legume intercropping results in above-and below-ground competitive advantages for understory legumes. WAJAE, 6(1).

WORLD BANK, 2006. Module 4: Investments in sustainable agricultural intensification. [ONLINE] Available at: http://siteresources.worldbank.org/EXTAGISOU/Resources/Module4_Web.pdf [Accessed 15th August, 2015]

WORTMANN, C. S., MAMO, M., MBURU, C., LETAYO, E., ABEBE, G., KAYUKI, K. C., CHISI, M., MATIVAVARIRA, M., XERINDA, S. \& NDACYAYISENGA, T. 2009. Atlas of sorghum production in eastern and southern Africa. The Board of Regents of the University of Nebraska, University of Nebraska-Lincoln.

YARON, D., VOET, H. \& DINAR, A. 1992. Innovations on family farms: the Nazareth region in Israel. Am. J. Agric. Econ., 74(2), pp.361-370.

YUDElMAN, M., RATTA, A. \& NYGAARD, D. F. 1998. Pest management and food production: looking to the future (Vol. 25). Intl Food Policy Res Inst. 